\title{
Conflict reporting in the South Pacific: A critical reflexive approach to Timor-Leste and West Papua
}

David Robie

Peace journalism has emerged belatedly in the context of critical studies in Oceania, where seminars over the past two years have addressed conflict reporting and the notion of peace journalism. Following a 10-year civil war in Bougainville in the 1990s and an ethnic conflict in the Solomon Islands in the early 2000s, this academic field has become increasingly important in the South Pacific context, even as other political upheavals have risen in Fiji, Vanuatu, Tahiti and Tonga. On the fringe of the South Pacific geopolitical region are the independent state of TimorLeste and two contested Melanesian provinces of Indonesia known collectively within Oceania as 'West Papua'. A Pacific media freedom report in October 2011 raised an unprecedented profile for both Timor-Leste and West Papua in the region, describing the latter in particular as a media 'blind spot'. Recent elections in both territories, as well as a controversy over a protracted miners' strike and the future of the Freeport mine in West Papua, bring to the fore ethical issues involving the performance of the Pacific region's news media. This paper examines the conflict-reporting framework in the South Pacific, and articulates two case studies in Timor-Leste and West Papua within the context of a widening global debate about peace journalism.

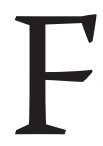
or a quarter of a century, the Indonesian invasion in December 1975 and subsequent occupation/annexation of TimorLeste was a news media 'blind spot' (Leadbeater, 2008, p. 168; Perrottet \& Robie, 2011; Robie, 1989, 1992). It remained largely out of the public consciousness in New Zealand and among Pacific Islands Forum member nations in spite of a close relationship with some of the territory's leaders with Australia and a significant Timorese diaspora in that country.

During the period of Indonesian control in defiance of the United Nations Security Council, which still recognised Portuguese sovereignty as the colonial power until the newly emergent state of Timor-Leste finally won independence in 2002, international media found it extremely difficult to visit there. The so-called Dili massacre on 12 
November 1991 changed that lack of awareness, when Kamal Bamadhaj, a 20-year-old New Zealander of Malaysian ethnicity, was killed along with at least 270 other people during a peaceful rally in a cemetery. But not immediately (Leadbeater, pp. 129-130). This author had his only personal experience of a 'kill fee' in his four-decade journalism career for the suppression of an op-ed page article about this massacre in a leading New Zealand daily newspaper.

The full-page broadsheet article had already been set up in type and laid out when it was 'pulled' from the paper. A New Zealander was among those who were brutally murdered by Indonesian troops that tragic day. Yet the New Zealand media were reluctant to publish the truth (Robie, 1994).

The four-page article, 'Terror in Timor', was subsequently published in a small circulation national magazine, NZ Monthly Review (Robie, 1992). In her 2006 book, Negligent neighbour: New Zealand's complicity in the invasion and occupation of Timor-Leste, human-rights advocate Maire Leadbeater foreshadowed what she saw as parallels with the Indonesian-ruled Melanesian province of 'West Papua' (or Irian Jaya, which was subsequently split into two provinces, Papua and West Papua); this was annexed in 1969 after an unsuccessful parachute invasion. "In West Papua, just as in East Timor, Indonesia tightly restricts the entry of journalists and international humanrights NGOs. Those that do manage to visit invariably report on the oppressive military presence and the tense and fearful atmosphere," she wrote (Leadbeater, 2006, p. 219).

Both Timor-Leste and West Papua are on the fringe of the South Pacific geopolitical region where conflicts have also been prevalent in the past two decades. Peace journalism or 'conflictsensitive journalism, as it is sometimes referred to in the Philippines, has emerged belatedly in the context of critical studies in Oceania, notably at the University of the South Pacific in Fiji, where seminars over the past two years have addressed conflict reporting and the notion of peace journalism (Robie, 2011; Singh, 2011). This academic field (Keeble et al., 2010; Shaw at al., 2011) has become increasingly addressed as an appropriate paradigm in a South Pacific context, following a 10-year civil war in Bougainville in the 1990s (Amnesty International, 1997) and an ethnic conflict in the Solomon Islands in the early 2000s (Kabutaulaka 2001; Fraenkel 2004a). With other political upheavals such as four coups d'état in Fiji in two decades, paramilitary revolts in Vanuatu, riots in Tahiti and Tonga, protracted conflict in Papua New Guinea's Highlands, and an earlier pro-independence insurrection in New Caledonia in the 1980s, conflict resolution poses challenges for the region's journalists and their education and training (Crocombe, 2005; Firth, 2005; Henderson \& Watson, 2005; Robie, 2004, 2011; Singh \& Prasad, 2008). A Pacific media freedom report in October 2011 raised an unprecedented profile for both Timor-Leste and West Papua in the region, characterising the latter as a media 'blind spot' (Perrottet \& Robie, 2011). Both territories experienced general elections earlier in 2012 and in West Papua a controversy over a protracted miners' strike and the future of the Freeport mine have been issues where the performance of the Pacific region's news media has been under scrutiny. This paper examines the conflict-reporting framework in the South Pacific, and articulates two case studies in TimorLeste and West Papua within the context of a widening debate about peace journalism.

\section{Notions of peace journalism: 'Portraying conflict in realistic terms'}

Peace journalism is hardly a new concept. Conceptual underpinning had been provided by Galtung and Ruge in 1965 and in later studies. It flourished significantly in parts of the globe in the 1990s, notably the Philippines, albeit frequently referred to there as 'conflict-sensitive journalism. In a South Pacific context, it has been considered seriously only recently. Centres of peace and conflict 
resolution research in Australia and New Zealand are increasingly turning to peace journalism as a subject for inquiry, though it is still in its infancy as a discipline for study in the Pacific. The discipline is sometimes seen as an approach in an academic and practical context that can arguably make sense of a region that has become increasingly complex, politically strained and violent (Robie, 2011; Singh, 2011). Yet peace journalism is generally eschewed by mainstream corporate media as a threat to the core values of 'traditional journalism' itself.

A critique of the corporate media view of the 'objectivity regime', said Robert Hackett (2011, p. 40 ), is that far from being detached and balanced, it contributes to the "production of systematically one-sided or ideological news accounts, and legitimises media practices that undermine democratic public life, such as a stance of cynical negativism". He adds that it also frames politics as a "game of insiders motivated only by electoral success". While Hackett acknowledges that such an interpretation is contested, he said there is widespread global agreement that traditional Western notions of media objectivity are 'in crisis':

Anglo-American journalism is increasingly dissolving within profit-driven conglomerates, its economic basis threatened by audience fragmentation, and its occupational ethos shifting from public service (however conservatively defined) to consumerism and commercialism. (Hackett, 2011, p. 40)

On the other hand, 'war journalism' often focuses on violence as its own cause and is less open to examining the deep structural origins of the conflict (Galtung \& Vincent, 1992). Heavy reliance on official sources leads to a general zero-sum analysis and deepens divisions. 'Peace' is defined as victory plus ceasefire. It is of little consequence that the deeper causes of the conflict remain unresolved, condemned to resurface later. After a period of violent conflict, such as the civil war in Bougainville, war journalism focuses on visible effects, i.e. those killed or wounded and damage to physical surroundings, not the impact on the people's psychology, sociology or culture. A decade after the end of the Bougainville war, the people are still recovering and rebuilding their lives in the autonomous region, emerging from under the shadow of a struggle popularised by New Zealand author Lloyd Jones in his 2006 novel Mister Pip. War journalism also dehumanises the 'enemy' and is "propaganda-oriented, elite-focused and victoryoriented, and tend[s] to concentrate on institutions (the 'controlled society')", as Keeble, Tulloch and Zollmann (2010, p. 2) notes in a book advancing the theoretical framework for journalism and conflict resolution.

In contrast, the notion of peace journalism offers a "voice to all parties", focused on the invisible effects of violence (trauma and glory, damage to the social structures), aimed to expose "untruths on all sides", is "people-oriented", gives "a voice to the voiceless" and is solution-oriented (ibid., p. 2)

According to Romano (2010), drawing on Lynch and McGoldrick (2005), peace journalism at the simplest level "relies on traditions of factbased journalism, with close scrutiny of word and images. Journalists must avoid emotive and imprecise expressions, dichotomies of good versus bad, a focus on the victimhood and grievances or the abuses and misdemeanours of one side only, and the use of racial and cultural identities when they are not necessary. Journalists must attribute unsubstantiated claims to their sources rather than presenting them as facts, avoid focussing on the victimhood or causes of one party to the exclusion of [an] other, and seek diverse sources and viewpoints" (Romano, 2010, p. 27).

In another definition, Shinar offered this antidote to 'event driven' war journalism dominated by official sources:

1. Exploring backgrounds and contexts of conflict formation, and presenting causes and options on every side so as to portray conflict in realistic terms, transparent to the audience.

2. Giving voice to the views of all rival parties.

3. Offering creative ideas for conflict 
resolution, development, peacemaking and peacekeeping.

4. Exposing lies, cover-up attempts and culprits on all sides, and revealing excesses committed by, and suffering inflicted on, people of all parties

5. Paying attention to peace stories and postwar developments (Shinar, 2007, p. 200).

In essence, much of this is good practice in traditional journalism but in times of conflict, journalists "do not always scrupulously" follow such ideals (Romano, 2010) and there have been frequent examples of this in the South Pacific (e.g. Field 2005; Moala 2001; Robie 2001; Woodley 2000) (see Table 1). In a Fiji context, flawed news media responses to the George Speight attempted coup of 19 May 2000 illustrated this. As seasoned Fiji Daily Post editor Jale Moala noted later:

[That] coup polarised the races in Fiji, or so it seemed. And in seeming to do so, it created a situation in which many reporters found it difficult to focus on the issues

Table 1

Pacific region media freedom matrix, July 2011

\begin{tabular}{|c|c|c|c|c|c|c|c|c|c|c|}
\hline Country & Killings & Abductions & Assaults & $\begin{array}{c}\text { Formal } \\
\text { censorship }\end{array}$ & $\begin{array}{l}\text { Police } \\
\text { arrests }\end{array}$ & $\begin{array}{c}\text { Criminal } \\
\text { libel }\end{array}$ & $\begin{array}{l}\text { FOI } \\
\text { Law }\end{array}$ & $\begin{array}{l}\text { Media } \\
\text { Council }\end{array}$ & $\begin{array}{l}\text { Medial } \\
\text { Plurality }\end{array}$ & $\begin{array}{l}\text { Media } \\
\text { group }\end{array}$ \\
\hline Australia & 0 & 0 & 0 & $x$ & 1 & $x$ & $\checkmark$ & \begin{tabular}{|c|} 
Australian \\
Press Council
\end{tabular} & P, TV, R, O P\&C & \\
\hline Cook Islands & 0 & 0 & 0 & $x$ & 0 & $x$ & $\sqrt{ }$ & $\begin{array}{l}\text { CI Media } \\
\text { Council }\end{array}$ & P, TV, R, O P\&C & \\
\hline $\begin{array}{l}\text { Federated States } \\
\text { of Micronesia }\end{array}$ & 0 & 0 & 0 & $x$ & 0 & $x$ & & & P, TV, R, O P\&C & \\
\hline $\mathrm{Fiji}$ & 0 & 0 & 1 & $\sqrt{ }$ & 2 & $\sqrt{ }$ & $x$ & \begin{tabular}{|c|} 
Media \\
Industry Dev \\
Authority;Fiji \\
Media Council \\
\end{tabular} & P, TV, R, O P\&C & $\begin{array}{c}\text { PINA, Fiji } \\
\text { Media Watch }\end{array}$ \\
\hline Kiribati & 0 & 0 & 0 & $\mathrm{x}$ & 0 & $\mathrm{x}$ & $x$ & & P, TV, R, O P\&C & \\
\hline Nauru & 0 & 0 & 0 & $\mathrm{x}$ & 0 & $x$ & $x$ & & P, TV, R, P & \\
\hline New Zealand & 0 & 0 & 0 & $x$ & 0 & $x$ & $\sqrt{ }$ & $\begin{array}{l}\text { NZ Press } \\
\text { Council }\end{array}$ & P, TV, R, O P\&C & $\begin{array}{c}\text { PIMA, PMCl } \\
\text { PMW }\end{array}$ \\
\hline Niue & 0 & 0 & 0 & $x$ & 0 & $x$ & $x$ & & Limited & \\
\hline Palau & 0 & 0 & 0 & $x$ & 0 & $x$ & $x$ & & LImited & \\
\hline $\begin{array}{l}\text { Papua New } \\
\text { Guinea }\end{array}$ & 0 & 0 & 0 & $x$ & 0 & $x$ & $x$ & & P, TV, R, O P\&C & PINA \\
\hline $\begin{array}{l}\text { Republic of the } \\
\text { Marshall Islands }\end{array}$ & 0 & 0 & 0 & $x$ & 0 & $x$ & $x$ & & TV, R, P P\&C & \\
\hline Samoa & 0 & 0 & 0 & $x$ & 0 & $\sqrt{ }$ & $x$ & & P, TV, R, O P\&C & JAWS \\
\hline Solomon Islands & 0 & 0 & 0 & $x$ & 0 & $x$ & $x$ & & P, TV, R, O P\&C & MASI \\
\hline Tonga & 0 & 0 & 0 & $x$ & 0 & $x$ & $x$ & & P, TV, R, O P\&C & \\
\hline Tuvalu & 0 & 0 & 0 & $x$ & 0 & $x$ & $x$ & & $\mathrm{P}, \mathrm{TV}, \mathrm{R}$ & \\
\hline Vanuatu & 0 & 0 & 1 & $x$ & 0 & $x$ & $x$ & & P, TV, R, O P\&C & MAV \\
\hline \multicolumn{11}{|l|}{ Other territories } \\
\hline Wallis and Futuna & 0 & 0 & 0 & $x$ & 0 & $x$ & & & & \\
\hline Timor-Leste & 0 & 0 & 0 & $x$ & 0 & $x$ & $x$ & Proposed & & \\
\hline West Papua & 2 & 5 & 8 & $\sqrt{ }$ & 2 & $\sqrt{ }$ & $x$ & AJl & & AJl \\
\hline French Polynesia & 0 & 0 & 0 & $x$ & 0 & $x$ & $\begin{array}{c}\sqrt{ } \\
\text { France }\end{array}$ & & P, TV, R, O P\&C & \\
\hline New Caledonia & 0 & 0 & 0 & $x$ & 0 & $x$ & $\begin{array}{c}\sqrt{ } \\
\text { France }\end{array}$ & & P, TV, R P\&C & \\
\hline
\end{tabular}

Source: Perrottet and Robie (2011). Pacific Journalism Review, 17(2), p. 154-155.

Key: $\quad \sqrt{ }=$ Yes; $\mathrm{X}=$ No, otherwise a number indicates the value. $\mathrm{P}=$ Press, $\mathrm{TV}=$ Television, $\mathrm{R}=$ Radio, $\mathrm{O}=$ Online, $\mathrm{P}=$ Public, $\mathrm{C}=$ Commercial 
from a totally impartial point of view as they were swept away by the euphoria of the moment and the tension and the emotion that charged the event. This was true of both indigenous Fijian and IndoFijian reporters alike.

Fear may have also played a role. As a result, the perpetrators of the terrorist action, led by George Speight, received publicity that at the time seemed to legitimise their actions and their existence (Moala 2001, p. 125).

According to Canadian journalist and mediadevelopment-in-conflict specialist Ross Howard, it does not take a war correspondent to recognise that journalism and news media can incite violent conflict. He offers several examples, including this:

In 1994, Radio Milles Collines in Rwanda incited genocide by employing metaphors and hate speech. Serbian state broadcasting during the 1995 and 1999 Balkan conflicts is almost equally infamous. Incompetent journalism and partisan news management can generate misinformation which inflames xenophobia, ethnic hatred, class warfare and violent conflict in almost any fragile state. The anti-Thai violence in Cambodia in 2003, triggered entirely by partisan media, is a more recent example. Radio Netherlands' website on counteracting hate media indicates that hate radio is currently operating on five continents. (Howard, 2009, p. 1)

Howard also noted that the potential for journalism to influence conflict resolution is often less recognised. Yet in recent years a range of literature has been developed critiquing the potential for media to "promote conflict resolution rather than war and violence" (Keeble, Tulloch \& Zollmann, 2010, p. 2). A 17-point plan for practising peace journalism by Keeble, Tulloch and Zollmann was summarised by Lynch and McGoldrick, who said that peace journalism is the use of insights from conflict analysis and transformation to "update the concepts of balance, fairness and accuracy in reporting" (2005, p. 5). Howard argues that peace journalism can "inject context, an appreciation for root causes, and a new capacity to seek and analyse possible solutions, to the otherwise daily repeating of violent incidents as news". For journalists and the news media in the South Pacific, there are growing opportunities for seeking alternative models that are more appropriate for the region's realities than Australian or New Zealand newsroom experience, where peace journalism is rarely debated. The Philippines is one such notable example where it has been one of the cradles of the development of peace journalism studies (Patindol, 2010) (see Table 1).

\section{Peace journalism amid Western Pacific conflict}

Reporting of both East Timor and West Papua over several decades has been, and still is, a "highly risky business" (Chesterfield, 2011, p. 30; Perrottet and Robie, 2011), as evinced by the killing of six Australian-based journalists during the invasion of East Timor in 1975 (immortalised in the 2009 Robert Connolly feature film 'Balibo', www.balibo.com).

In 2011, Perrottet and Robie reported in a 39-page Pacific media freedom report that there had been "two killings of journalists; five abductions, or attempted abductions; 18 assaults (including repeated cases against some journalists), censorship by both the civil and military authorities and two police arrests, but no charges" in West Papua during the previous year (p. 153).

Nick Chesterfield, founding editor of an emerging independent 'citizen' news agency, West Papua Media, pointed out-in what is arguably the most comprehensive academic conference that debated the future of West Papua in Sydney-in November 2011 that "accountability is always the simplest solution to combating impunity". He called for an "aggressive culture of investigative journalism" and the development of appropriate skills to expose who was accountable for "human rights abuse, military business mafias and corruption, human insecurity [or] environmental vandalism". He argued that both academia and the international media needed 
to take a strong role in this development to enable Papuan journalists and citizen media to report "without fear, hindrance or threat".

According to Chesterfield, journalistsPapuan and outsiders alike-were under constant threat for reporting West Papua even as four journalists died in suspicious circumstances in 2010 alone. Journalists who report fearlessly are targets, although most journalists in West Papua simply put up with it; they have no other option. What can the international media do to lessen their risk?

Partly in response to this danger and partly to give local journalists a voice globally, West Papua Media (WPM) was started in 2008. It aims to provide a professional service to international media covering West Papua, ensuring high quality, verifiable reporting gets in to the international media directly from the ground and not from those who seek to distort the truth of daily experience in Papua. (Chesterfield, 2011a, p. 32)

Noting that a foreign media ban had been in place since 2004 (IFJ, 2006), Kayt Davies documented and analysed the strategies developed by WPM to "both bolster its credibility and protect its journalists and sources" (Davies, 2012, p. 70). She lamented that in spite of calls by the International Federation of Journalists and others for an end to the Indonesian ban on foreign media and on humanitarian organisations such as the International Committee of the Red Cross, "the ban persists ... and has provided the context for the emergence of a vibrant network of civil resistance journalists" (p. 71). She cites Chesterfield, when describing WPM's safety protocol and training, as saying:

There is an academic awareness that Indonesian security forces will kill journalists and anyone speaking to journalists, and that's always been the way. With Balibo, the film, it's certainly come back into people's consciousness, and that's fantastic. But we've got a long way to go with mainstream Australian media, if they want to cover it at all, and quite often the conditions of safety are an excuse for many mainstream Australian media people to refuse to cover it ... (pp. 76-77)

New Zealand has parallels with the Australian experience. Maire Leadbeater argued that solidarity activists have struggled to make the issue better known outside the human rights community. "As a New Zealand activist," she observed, "I have found that when we host a West Papuan human rights leader, it is hard to persuade local journalists (or perhaps their editors) that they should make time to interview our guest" (Leadbeater, 2008, p. 169).

Radio New Zealand International is an exception to this pattern. It frequently interviews West Papuan representatives with varying political reviews, both those who are on the ground as well as those who are in exile ... New Zealand diplomats do not get the run around [experienced by journalists] when they request permission to visit West Papua ... NZ Embassy staff make regular visits to West Papua to oversee aid projects, including a special training programme in conflict resolution and community policing for the West Papuan police. (p. 171)

According to Radio New Zealand International news editor Walter Zweifel, the international community regards the West Papua situation as "largely settled" and that the problems were an internal affair for Indonesian authorities to resolve. The main reason for the lack of interest, Zweifel believed, is "the absence of First World protagonists, most notably Anglo-Saxons” (p. 69).

With concessions for autonomy after the demise of the Suharto regime [in May 1998], the Papua issue has practically disappeared from the international scene ... We get information about newsworthy developments nowadays most often through email. Human rights groups, pressure groups, and churches, tend to alert us what is happening. At times, we pick through English-language websites for information. (p. 69). 
Considering the fact that Papua New Guinea shares a land border with Indonesia's two disputed Papuan provinces, hosts several thousand Papuan refugees and has strong Melanesian cross-cultural bonds, it seems reasonable to expect that news media coverage in that country would be more readily prepared to cover Papuan affairs. But this is not the case.

In a content-analysis research conducted by Papoutsaki and Matbob (2006) on PNG daily and weekly newspapers, while comparing coverage in March - May 2006 with the corresponding period in 1984, the authors found a "dramatic decline in the number and length of [Papua] stories and voices heard within them" (p. 93). In like manner, in a panel on conflict reporting at the International Association for Media and Communication Research (IAMCR) in Durban, South Africa, in July 2012, Dr Beate Josephi argued a case for the responsibility of news organisations to project the visibility of conflicts as an 'ethical necessity':

$[R]$ eporting conflict, such as in the case of West Papua, should be seen as an ethical necessity. Journalists and editors shape the world the media represents, even if now social media opens the way for other actors to participate more fully. Visibility-whether in the traditional or social media-is the very basis on which entry into the media public sphere is made. (Josephi \& Robie, 2012)

\section{Case study 1: Timor-Leste, a state in transition}

After almost a quarter century under Indonesian rule, East Timor gained its independence as the Democratic Republic of Timor-Leste and embarked on a foreign policy sandwiched between its problematic relationship with the former neocolonial power and also with Australia and the 16 nations of the Pacific Islands Forum (PIF). The nation had originally been colonised by Portugal in the sixteenth century and was known as Portuguese Timor until the 'Carnation revolution' against the Caetano regime in April 1974 led to Lisbon divesting itself of its former colonies. In the subsequent power vacuum, East Timor unilaterally declared independence on 28 November 1975. But fearing a 'communist' government on its doorstep, the Indonesian military invaded the tiny country in December at the height of the so-called Cold War (Robie, 1989; Nevins, 2005). Western governments, including Australia and New Zealand, generally supported the invasion and ignored the atrocities (including the killing of six Australian-based journalists) (Leadbeater, 2006). Indonesian authorities formally declared East Timor as its 27th province on 17 July 1976.

However, the UN Security Council opposed the invasion and occupation and maintained a monitoring brief on Indonesia's harsh rule of the colony as a "non self-governing territory under Portuguese administration" (Nevins, 2005). An estimated 205,600 Timorese died under Indonesian occupation $^{1}$ but the so-called Dili Massacre on 12 November 1991 served as a catalyst for mounting international opposition when Indonesian troops opened fire on unarmed mourners in a Santa Cruz cemetery on the outskirts of the capital and killed at least 271 people, including New Zealander Kamal Bamadhaj (The Santa Cruz massacre, ETAN, 2011). Footage of the massacre by cameraman Max Stahl (screened on ITV in the 1992 documentary 'Cold blood: The massacre of East Timor') and eyewitness accounts by American journalists Amy Goodman and Allan Nairn, who were also beaten up by Indonesian troops, caused outrage around the world.

The massacre also spawned new activist groups such as the East Timor Action Network (ETAN) and a new wave of opposition to Indonesian rule in Australia, New Zealand, Portugal and the United States. Statements by Indonesian military officers also fuelled the opposition, such as Commander-in-Chief Try Sutrismo, who was quoted two days after the massacre:

The army cannot be underestimated. 
Finally we had to shoot them. Delinquents like these agitators must be shot, and they will be ... (Carey, 1995, p. 50)

After a wave of civil unrest forced Indonesian President Suharto to end his three-decades-long rule and resign in 1998, a United Nations-sponsored agreement between Indonesia and Portugal paved the way for an UN-supervised referendum in August 1999. An overwhelming 78 percent voted against the Indonesian autonomy proposal and unleashed a destructive and violent 'scorched earth' campaign by pro-Jakarta militia and some elements of the Indonesian armed forces. An Australian-led international peacekeeping force was despatched in September to keep order and the UN Transitional Administration in East Timor (UNTAET) took control in October 1999. Timor-Leste became an independent state on 20 May 2002 and former Fretilin guerrilla leader Xanana Gusmão was sworn in as the country's first president.

After a further outbreak of violent clashes in mid-2006, the first prime minister, Fretilin leader Dr Mari Alkatiri, was forced to resign and was replaced by Nobel Peace Prize winner Dr José RamosHorta. As a New Zealand aid project in support of the fledgling nation, the New Zealand Electoral Commission resolved to send a six-member journalist mission to Timor-Leste in 2007 to monitor progress with the evolving media and its contribution to the emerging democracy. This author was recruited for this mission, which reported on both the first presidential and parliamentary elections conducted by the country's institutions. While commending the Timorese media for their efforts in covering the first elections, the mission noted the "absence of an overall information strategy for Timor-Leste, which includes greater media penetration as a critical component". This meant that the nation would risk "being information poor" for years to come. The mission was also critical of a lack of a "whole-hearted commitment" by leading politicians for a free and independent media. Recommendations included the following:

- Further training and development in holding political and public figures to account by following up on statements, political promises, and political and government policies will strengthen journalism and public discussion in Timor-Leste.

- The mission believes that a specific media accountability mechanism to address complaints about and from the media with respect to both political and election processes and other issues would strengthen the reporting of future elections and the new government.

- The mission believes that the development of media law frameworks should be enabling rather than prescriptive, and promote and protect freedom of expression and information. Punitive provisions such as criminalisation of defamation, the licensing of journalists or media organisations at state discretion, or onerous regulation of right of reply practices should not be enacted.

- The mission believes that physical intimidation of journalists should result in criminal prosecution as a means of creating a culture of increased safety for reporters.

(McGregor et al., 2007)

Ironically, during the 2012 Timor-Leste elections, a senior military officer once recommended by the United Nations for criminal prosecution in 2006 won over the incumbent, Ramos-Horta, popular in both Australia and New Zealand, and was elected president. José Maria de Vasconcelos, known by his military nom de plume as Taur Matan Ruak (or 'Two Sharp Eyes'), also defeated the favoured former revolutionary party Fretilin leader Francisco 'Lu Olo' Guterres in the run-off poll. He campaigned widely in some 152 villages over a six-month period prior to the elections ( $\mathrm{Ba}-$ chelard, 2012).

\section{Case study 2: West Papua strike and 'new wave' independence activism}

Indonesia launched an ill-fated airborne invasion the West Papua region of the former Dutch East 
Indies in 1961. While it did not succeed in annexing the region with military force, it achieved this through a disputed 'Act of Free Choice' supervised by the United Nations in 1969. However, since then the Free Papua Movement (OPM) has waged a sporadic guerrilla struggle against Indonesian rule. Peaceful civilian protests, including the hoisting of the banned Morning Star flag, a symbol of independence, have also marked Indonesian rule. The year 2010 "ushered in a new wave of West Papuan independence politics" (King et al., 2011, p. 3) and this momentum has been bolstered by a youthful 'tougher stance' on West Papuan selfdetermination with the support of social media.

Political leaders of the Pacific Islands Forum (PIF) met in Auckland, New Zealand, for the 40th time in a high-profile conference the week leading into the Rugby World Cup. As well as the Australian and New Zealand prime ministers and presidents, nobles and chief ministers from all 16 member countries of the Forum-except Fiji, which was suspended in 2009 because of the military regime and failure to keep to an immediate timetable to restore independence-strong international delegations also represented Northern Hemisphere countries for parallel events. United Nations Secretary General Ban Ki-moon visited Auckland after 'global warming' whistle-stop tours of Kiribati and the Solomon Islands; the European Commission president José Manuel Barroso and 50-strong delegations from both China and the United States were strong participants (see Figure 1).

A Papua New Guinean student-journalist asked Ban Ki-moon a critical question about West Papua and drew a remarkable response from the Secretary-General. The Secretary-General said the issue of human rights was something that should be discussed with the Decolonisation Committee of the United Nations General Assembly, adding it could deal with any country regardless of whether it was an independent state or self-governing territory (Yamo, 2011). But while the news item on Pacific Scoop caused international ripples, the significance was lost on most local journalists.
Ban Ki-moon: And when [the issue] comes again, whether you are an independent state or a non-self-governing territory or whatever, the human rights is inalienable and a fundamental principle of the United Nations. We will do all to ensure that people in West Papua, their human rights will be respected.

Reporter: Will a human-rights fact-finding mission be dispatched to West Papua at some time?

Ban Ki-moon: That is the same answer [to a previous question on Fiji] that should be discussed at the Human Rights Council among the member states. Normally the Secretary General acts on the basis of a mandate given by inter-governmental bodies. (Yamo, 2011)

Tension was already high in West Papua in mid-September when workers at the FreeportMcMoRan's Grasberg mine, one of the largest copper and gold extraction sites in the world, went on strike. They demanded large wage increases to bring their income in line with what the company paid its workers in other countries. The mine had been a source of tension since Indonesia annexed the territory of West Papua and ratified the socalled 'Act of Free Choice', which has been labelled

\section{Figure 1}

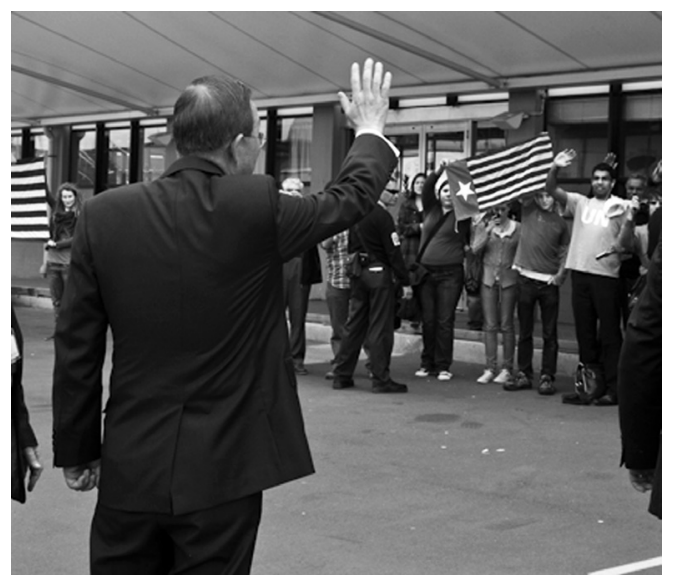

UN Secretary-General Ban Ki-moon waves to demonstrators with a banned Morning Star pro-independence flag from West Papua, in Auckland, September 2011. Photo: @ Karen Abplanalp / Pacific Media Centre 2011. 
by critics as an "act of no choice". On 10 October 2011, security forces opened fire on striking miners as they tried to gain access to company premises.

One man, Petrus Ayamseba, was killed in the incident. Several others were rounded [up], and one these, Leo Wandagau, died of his injuries five days later. There have also been three incidences of shooting along the road that leads to the Freeport mine. Three contract workers were killed in an ambush on 14 October 2011, and then another three men were killed a week later (West Papua at boiling point, 31 October 2011).

According to West Papua Project analyst Jim Elmslie, the strike has "irrevocably transformed" the status quo at the mine, "once the epitome of aggressive American capitalism" (Elmslie, 2011). The development at the mine loosely coincided with the shooting of six Papuans at the end of a three-day Papuan People's Congress in the outskirts of the capital of Jayapura on 19 October 2011 (Moffiet, 2012). Already alerted to the worsening situation at Freeport, Pacific Scoop responded to a Pacific Journalism Review research report on press freedom in the region (Perrottet \& Robie, 2011b), which included scathing sections about West Papua and warned that the region posed the worst situation confronting journalists. Describing the situation as a "media black spot" in New Matilda magazine (Perrottet \& Robie, 2011a), the authors said reporting the region was fraught with obstacles:

Jakarta still upholds its prohibition on all foreign journalists and media workers from entering either province in West Papua, unless pre-approved under a slow and bureaucratic process from the Ministry of Information. Even after approval, journalists are always accompanied by a minder from the Badan Intelijen Nasional (National Intelligence Body). Only three foreign journalists have been allowed access to West Papua in 2011. Unsurprisingly, few journalists choose this official route, with many opting to travel into West Papua via unofficial means, a process unavailable to Jakarta-based correspondents under threat of immediate expulsion. Human rights workers regularly report that security forces harass and intimidate those seen talking to foreign journalists, though many still take the risk when a foreign journalist is present. (Chesterfield, 2011b, p. 178)

The barriers to free reporting are perhaps a contributing factor to the almost negligible news reporting in the New Zealand media of West Papuan issues, apart from occasional snippets about the Freeport mine. A major exception has been Radio New Zealand International, which, despite very limited resources compared to its Radio Australia cousins, doggedly provides coverage on the legacy of armed struggle in West Papua and Bougainville. News editor Walter Zweiffel (2010, p. 69) makes a passionate defence of his public broadcaster's role in "producing the first draft of history".

The Free Papua Movement, or OPM, has been involved in an unsuccessful military struggle whose end is not in sight. The conflict has led to prolonged misery and abuse that has cost the lives of tens of thousands of people. Today, raising the separatist Morning Star flag can result in a longer prison sentence than a conviction for manslaughter in New Zealand. (Zweifel, 2010, p. 69)

In this context, in mid-October Pacific Scoop began reporting on issues related to the 2011 Papuan People's Congress, the third such conference in as many decades and covered the first two days of this event. Naturally, when warnings of an impending military crackdown emerged along with a build-up of heavily armed security forces around the congress perimeter, the news service stepped up its coverage. Along with stories filed by student-journalists and staff, PMC collaborated with West Papua Media, human-rights groups and media freedom advocates to piece together reports of atrocities. Extensive video footage was 
used to corroborate the stories and reports. In spite of the developing crisis, New Zealand news media took little notice.

A content analysis of a two-week period between the start of the military crackdown from 19 October to 2 November 2011 showed that Pacific Scoop published 66 percent of the total of 99 news stories carried by main New Zealand news media websites about the West Papua crisis (see Table 2). By comparison, during the same period, the Sydney Morning Herald published five stories, four of them insightful and contextualised reports by the newspaper's Jakarta correspondent Tom Allard. Two Knowledge Basket databases, Newtext (NZ media) and Niustext (Pacific media), and the Pacific Scoop internal search engine were used to compile the statistics (see Table 2.)

Against the zero exposure trend on West Papua in New Zealand media, the leading monthly lifestyle magazine Metro, which established its existence based on quality investigative reporting under the founding editorship of Warwick Roger in 1984, commissioned a cover story for its December 2011 edition. Currently edited by Simon Wilson, who has boosted circulation with a return to rigorous reporting, the magazine took on an investigation into the questionable ethics of the NZ Superanuation Fund investing some
NZ\$20 million in a mining company tainted with persistent Indonesian human-rights allegations for more than three decades. The article, entitled 'Blood Money', was written by Karen Abplanalp, an independent photojournalist on the Asia-Pacific Journalism course at AUT University. She began her article thus:

On October 10 this year, Indonesian police assigned to protect the world's largest gold and copper mine opened fire on striking miners, killing two. The miners were unarmed and their strike was legal. Since this incident, five more miners have been killed in suspicious circumstances. It was the latest incident in a long line of human rights abuses, not to mention ongoing environmental devastation, associated with the mine. The New Zealand Superannuation Fund, which is a signatory to the United Nations Principles for Responsible Investing (UNPRI) charter, has shares in the enterprise. Why? (Abplanalp, 2011, p. 38)

The mine is the largest taxpayer in Indonesia with an annual tax bill of US\$1.4 billion and Abplanalp reported that human-rights abuses as well as environmental impacts were well-documented long before NZSF invested in it. She noted that in 2006 the US embassy in Wellington described

Table 2

New Zealand media coverage of the West Papua crisis, 19 October - 2 November 2011

\begin{tabular}{lccc}
\hline News media organisation & Medium & Stories & Database \\
\hline New Zealand Herald & Newspaper & 1 & Newztext \\
\hline Radio NZ National & Newsweb & 0 & Newztext \\
\hline Scoop Media & Newsweb & 3 & Newztext \\
\hline Stuff.co.nz [Fairfax Media] & Newsweb & 0 & Newztext \\
\hline Pacific Media Centre & Newsweb & 14 & Niustext \\
\hline Pacific Scoop [on PMC] & Newsweb & 9 & Niustext \\
\hline Radio NZ International & Newsweb & 14 & Niustext \\
\hline Pacific Scoop & Newsweb & 58 & PS Search \\
\hline Total & & 99 &
\end{tabular}

Source: Robie, D. (2011). Compiled from two Knowledge Basket databases, Newtext (NZ media) and Niustext (Pacific media), and the Pacific Scoop internal search engine were used to compile the statistics. 
West Papua in a cable as a "war zone in many places" and "it has all the makings of the next East Timor, except that this time, Jakarta will not let go" (Perrottet, 2011). She added that NZSF chief executive Adrian Orr was "immensely proud" of the investment in spite of fund's self-imposed standards, which included "no complicity in abuses". Abplanalp also revealed in a Pacific Media Watch news item that she had became interested in the issue from attending a public talk by Indonesia Human Rights Committee spokesperson Maire Leadbeater (Perrottet, 2011). She later expounded on her research methodology in a paper published in Pacific Journalism Review (Abplanalp, 2012).

On 9 November, Amnesty International called on the Indonesian government to "act immediately" on the Indonesian National Human Rights Commission (Komnas HAM) findings that human-rights violations were committed by security forces in breaking up the People's Congress ('Indonesia must act quickly', Pacific Scoop, 9 October 2011). The Komnas HAM investigation team found a range of human-rights violations allegedly committed by the Indonesian security forces on 19 October 19, including opening fire on participants of the peaceful gathering and beating and kicking them. The Amnesty International statement said:

If the investigations find that the security forces committed unlawful killings or torture or other ill-treatment, then those responsible, including persons with command responsibility must be prosecuted in proceedings which meet international standards of fairness, and victims provided with reparations. (Indonesia: Government must act, 2011)

On 11 May 2012, the High Court of Papua upheld charges of 'treason' against Forkorus Yaboisembut (self-styled President), Edison Warami (Prime Minister) and three others for declaring independence at the Papuan People's Congress and given three-year sentences in defiance of protests by international human-rights groups ('High court upholds three-year sentences', West Papua Media, 11 May 2012). During the West Papuan regional elections in mid-April, a journalist was killed during an armed attack on an aircraft at Mulia Airport by unidentified gunmen.

\section{Conclusion}

Against such a contested and fraught mediascape, how can notions of peace journalism or conflict sensitive journalism take root? As Howard noted (2009, p. 1), conventional journalism training and development "generally contain little or no reference to the wisdom of five decades of academic and professional study of conflict". He argued that conflict analysis theory and skills were still not considered mainstream journalism prerequisites or practices. However, Howard also cited examples of the gradual development of journalism training courses that recognised 'conflict-sensitive journalism' as a methodology. While such training includes core journalism values and skills, this approach includes an introduction to conflict analysis, the concept of conflict and most common causes, the forms of violence by which conflict is played out, and some insights into the techniques of resolution.

On an optimistic note, Howard suggested these added capabilities developed through education and training lead to a "better story selection and much more insightful writing and broadcasting" (p. 2). He adds: "At best, they substantially expand a stressed community's dialogue and possibly offer glimpses of common ground." Similarly, Robert Hackett argued that peace journalism and media reform/communication rights paradigms have common principles. Strategically, they have common opponents such as "ear propaganda, and the institutions that support it, authoritarian governments that stifle press freedom, the post 9/11 political climate of fear" and the so-called 'war on terror' (Hackett, 2011, p. 59).

Peace journalism or conflict-sensitive journalism education and training ought to provide a context for journalists to ensure that both sides are included 
in any reports as is demonstrated in the Timor-Leste and West Papua case studies. The reporting would also include people who condemn the violence and offer solutions. Blame would not be levelled at any ethnicity, nor would combatants be repeatedly identified by their ethnicity. But the reporting would constantly seek to explain the deeper underlying causes of the conflict. This approach to journalism could offer some hope for conflict resolution in the Pacific and a more peaceful future.

Countries listed are the 16 Pacific Island Forum (PIF) member nations, including military ruled Fiji, which is currently suspended. Also listed are the French territories in the South Pacific and the current and former Indonesian Pacific colonies. Media groups are Alliance of Independent Journalists, Indonesia (AJI); Journalists Association of Western Samoa (JAWS); Media Association of the Solomon Islands (MASI); Media Association Blong Vanuatu (MAV); and Pacific Media Centre and Pacific Media Watch (PMC/PMW). In West Papua, under Indonesian law, makar (subversion) is also used repressively against journalists as well as criminal libel. The Papuan press is also regularly labelled as 'proseparatist', a significant threat against journalists seen to be giving too much coverage to self-determination sentiment.

\section{Note}

1. Sourced from the 2,500-page report entitled, Chega ['Enough!'], by the Commission for Reception, Trust and Reconciliation in East Timor. The breakdown of these figures stated that there had been at least 102,800 conflictrelated deaths in the conflict, 18,600 killings and 84,200 'excess' deaths from hunger and illness.

\section{References}

Abplanalp, K. (2011, December). Blood money. Metro magazine. Retrieved from www.pmc. aut.ac.nz/sites/default/files/file_bin/201111/ Metro_Dec2011_FreeportSuperfund_ pp43-49.pdf on 23 November 2011.
Abplanalp, K. (2012). 'Blood Money': A NZ investigative journalism case study. Pacific Journalism Review, 18(1), 128-147.

Bachelard, M. (18 April 2012). Controversial former army chief emerges to lead East Timor. Pacific Scoop. Retrieved from http://pacific.scoop. co.nz/2012/04/controversial-former-army-chiefemerges-to-lead-east-timor/ on 11 May 2012.

'Balibo' (2009). Directed by Robert Connolly. Footprint Films. Feature film. Melbourne. www.balibo.com.

Carey, P. (1995). Historical background. In S. Cox (Ed.), Generations of resistance (pp. 13-55). London: Cassell.

Chesterfield, N. (2011a). Free the people? Free the media! Broadcasting Papua's songs of freedom. In P. King, J. Elmslie \& C. Webb-Gannon (Eds.), Comprehending West Papua (pp. 29-36). Sydney: Centre for Peace and Conflict Studies, University of Sydney.

Chesterfield, N. (2011b). West Papua. In A. Perrottet \& D. Robie (2011a). Pacific press freedom 2011: A status report. Pacific Journalism Review, 17(2). Retrieved from www. pjreview.info/articles/pacific-media-freedom2011-status-report-513 on 23 November 2011.

'Cold blood: The massacre of East Timor' (1992). Directed by Peter Gordon. Yorkshire Television. [Documentary]. Retrieved on the BFI film database from http://ftvdb.bfi.org.uk/sift/ title/466744 on 11 May 2012.

Crocombe, R. (2005). Regionalism and the reduction of conflict. In J. Henderson \& G. Watson (Eds.), Securing a peaceful Pacific (pp. 153-60). Christchurch: Canterbury University Press.

Davies, K. (2012). Safety vs credibility: West Papua media and the challenge of protecting sources in dangerous places. Pacific Journalism Review, 17(2), 69-82.

Elmslie, J. (23 November 2011). Why now? A West Papua backgrounder. New Matilda. Retrieved from http://newmatilda.com/2011/11/23/ why-now-west-papua-backgrounder on 23 November 2011.

Field, M. (2005). Speight of violence: Inside the Fiji 2000 coup. Auckland: Reed.

Firth, S. (2005). A new era in security. In J. Henderson \& G. Watson (Eds.), Securing a peaceful Pacific (pp. 153-60). Christchurch: Canterbury University Press.

Fraenkel, J. (2004). The coming anarchy in Oceania?: A critique of the 'Africanisation of the South Pacific' thesis. Journal of Commonwealth and Comparative Politics, 42(1).

Galtung, J., \& Ruge, M. (1965). The structure of foreign news: The presentation of the Congo, 
Cuba and Cyprus crises in four Norwegian newspapers. Journal of International Peace Research, 1, 64-91.

Galtung, J., \& Vincent, R. (1992). Global glasnost: Toward a new world and information order? Creskill, NJ: Hampton Press.

Hackett, R. A. (2011). New vistas for peace journalism: Alternative media and communication rights. In I. S. Shaw, J. Lynch \& R. A. Hackett (Eds.), Expanding peace journalism: Comparative and critical approaches (pp. 35-69). Sydney: Sydney University Press.

Henderson, J. (2005). Introduction: Pacific conflict - how much and why? In J. Henderson \& G. Watson (Eds.), Securing a peaceful Pacific (pp. 153-60). Christchurch: Canterbury University Press.

Henderson, J., \& Watson, G. (Eds.). (2005). Securing a peaceful Pacific. Christchurch: Canterbury University Press.

High court upholds three-year sentences for Forkorus and his colleagues. (11 May 2012). West Papua Media, citing Jubi. Retrieved from http://westpapuamedia.info/2012/05/12/ high-cort-upholds-three-year-sentences-forforkorus-and-his-colleagues/ on 11 May 2012.

Howard, R. (2009) The case for conflict sensitive journalism. Centre for Journalism Ethics, School of Journalism and Mass Communication, University of Wisconsin-Madison. Retrieved from http://www.journalismethics.ca/ global_journalism_ethics/conflict_sensitivity_in_practice.htm on 5 September 2010.

Indonesia: Government must act on Komnas HAM's findings of human rights violations at Papuan Congress (9 November 2011). Amnesty International [media release]. Retrieved from www.amnesty.org.nz/news/ indonesia-government-must-act-komnasham $\%$ E2\% $80 \% 99$ s-findings-human-rightsviolations-papuan-congress on 25 November 2011.

Indonesia must act quickly on Papua violations report, says Amnesty (9 November 2011). Pacific Scoop. Retrieved from http://pacific. scoop.co.nz/2011/11/indonesia-must-actquickly-on-human-violations-report-saysamnesty-international/ on 25 November 2011.

International Federation of Journalists (IFJ). (2006).

Jones, L. (2006). Mister Pip. Auckland: Text Publishing.

Josephi, B., \& Robie, D. (2012). The visibility of conflicts as ethical necessity: A West Papua case study. Panel presentation at the International
Association for Media and Communication Research (IAMCR), Durban, South Africa, 15-19 July 2012.

Kabutaulaka, T. (2001). Beyond ethnicity: The political economy of the Guadalcanal crisis in Solomon Islands. Suva: SSGM Working Paper.

Keeble, R. L., Tulloch, J., \& Zollmann, F. (2010). Introduction: Why peace journalism matters. In R. L. Keeble, J. Tulloch \& F. Zollmann (2010), Peace journalism, war and conflict resolution (pp. 1-12). New York: Peter Lang.

Keeble, R. L., Tulloch, J., \& Zollmann, F. (2010). Peace journalism, war and conflict resolution. New York: Peter Lang.

King, P., Elmslie, J., \& Webb-Gannon, C. (Eds.) (2011). Comprehending West Papua. Sydney: Centre for Peace and Conflict Studies, University of Sydney.

Leadbeater, M. (2006). Negligent neighbour: New Zealand's complicity in the invasion and occupation of Timor-Leste. Nelson: Craig Potton Publishing.

Leadbeater, M. (2008). Media blind spot over West Papua. Pacific Journalism Review, 14(1), 168-174.

Lynch, J., \& McGoldrick, A. (2005). Peace journalism. Stroud, Hawthorn Press.

McGregor, J., Lind, C., Geary, S., Misa, T., Robie, D., \& Zweifel, W. (2007). New Zealand media observation mission report: 2007 Timor-Leste elections. Wellington: NZ Electoral Commission. Retrieved from http://kauri.aut.ac.nz:8080/dspace/bitstream/123456789/13/1/TL\%20Final\%20 version.pdf on 11 May 2012.

Matbob, P., \& Papoutsaki, E. (2006). West Papuan 'independence' and the Papua New Guinea press. Pacific Journalism Review, 12(2), 87-105.

Moala, J. (2001). Political reporting and editorial balance. In D. Robie (Ed.), The Pacific journalist: A practical guide (pp. 125-143). Suva, Fiji: University of the South Pacific Book Centre.

Moffiet, N. (18 January 2012). Human rights abuses and the media question of genocide in West Papua. Pacific Media Centre Online. Retrieved from www.pmc.aut.ac.nz/articles/ human-rights-abuses-and-question-genocide-west-papua on 11 May 2012.

Nevins, J. (2005). A not-so-distant horror: Mass violence in East Timor. London: Cornell University Press.

Pacific Scoop Pacific Islands Forum archive. (20 September 2011). Retrieved from http:// pacific.scoop.co.nz/category/pacific-islandsforum/ on 11 May 2012. 
Patindol, J. J. C. (2010). Building a peace journalist's network from the ground: The Philippine experience. In R. L. Keeble, J. Tulloch \& F. Zollmann (Eds.), Peace journalism, war and conflict resolution (pp. 193-206). New York: Peter Lang.

Perrottet, A. (2011). Freeport mine investigation in Metro magazine challenges super fund. Pacific Media Watch 7752. Retrieved from www.pmc. aut.ac.nz/pacific-media-watch/nz-freeportmine-investigation-metro-magazine-challenges-super-fund-7752 on 25 November 2011.

Perrottet, A., \& Robie, D. (24 October 2011a). Papua a media black spot, New Matilda. Retrieved from http://newmatilda. com/2011/10/24/papua-media-black-spot on 23 November 2011.

Perrottet, A., \& Robie, D. (2011b). Pacific press freedom 2011: A status report. Pacific Journalism Review, 17(2). Retrieved from www. pjreview.info/articles/pacific-media-freedom2011-status-report-513 on 23 November 2011.

Robie, D. (1989). Blood on their banner: Nationalist struggles in the South Pacific. London: Zed Books.

Robie, D. (1994). Media hypocrisy on East Timor [Review]. Pacific Journalism Review, 1(1): 97-98.

Robie, D. (April 1994). Terror in Timor. NZ Monthly Review, 333, 14-18.

Robie, D. (2004). Mekim Nius: South Pacific media, politics and education. Suva: University of the South Pacific Book Centre.

Robie, D. (2011). Conflict reporting in the South Pacific: Why peace journalism has a chance. Journal of Pacific Studies, 31(2), 221-240.

Romano, A. (2010). International journalism and democracy: Civic engagement models from around the world. New York: Routledge.
Shaw, I., Lynch, J., \& Hackett, R. (2011). Expanding peace journalism: Comparative and critical approaches. Sydney: Sydney University Press.

Singh, S. (2011). Peace journalism. Media objectivity and Western news values in fragile Pacific island states: Reflections from Pacific island journalists, Journal of Pacific Studies, 31(2), 259-275.

Singh, S., \& Prasad, B. (2008). Coups, media and democracy in Fiji. In Singh and Prasad (Eds.), Media and democracy in Fiji (pp. 1-8). Fijian Studies: A journal of contemporary Fiji. Suva: Fiji Institute of Applied Studies.

South Asia Human Rights Documentation (31 August 2006). West Papua: Swept under batik carpet? Retrieved from www.unpo.org/article. php?id=5327 on 24 November 2006 (Accessed on 26 August 2010).

The Santa Cruz massacre, November 12, 1991 (2011). East Timor Action Network (ETAN). Retrieved from www.etan.org/timor/SntaCRUZ.htm on 12 May 2012.

West Papua Advocacy Team (WPAT). (2010). West Papua Report. Retrieved from www.etan. org/issues/wpapua/2010/1006wpap.htm on 11 May 2012.

Woodley, B. (2000). Courage under fire, The Weekend Australian, Media section, 8-14 June, p. 6.

Yamo, H. (7 September 2011). Human rights 'fundamental' in member countries and worldwide, says UN chief. Retrieved from http:// pacific.scoop.co.nz/2011/09/human-rightsfundamental-in-member-countries-andworldwide-says-un-chief/ on 23 November 2011.

Zweifel, W. (2010). Reporting war: Covering the Pacific: Radio NZ International and West Papua as a case study. Pacific Journalism Review, 16(1), 68-71. 